\title{
The Genetic Drift of Indonesian Avian Influenza A H5N1 Viruses During 2003-2008
}

\author{
NI LUH PUTU INDI DHARMAYANTI ${ }^{1 *}$, GINA SAMAAN ${ }^{2}$, \\ FERA IBRAHIM $^{3}$, RISA INDRIANI ${ }^{1}$, DARMINTO ${ }^{1}$, AND AMIN SOEBANDRIO ${ }^{3}$ \\ ${ }^{1}$ Indonesian Research Center for Veterinary Science, Agency for Agricultural Research and Development, \\ Departemen Pertanian, Jalan RE Martadinata 30, Bogor 16114, West Java, Indonesia; \\ ${ }^{2}$ National Centre for Epidemiology and Population Health, Australian National University, \\ Canberra, ACT 0200, Australia; \\ ${ }^{3}$ Microbiology Department, Medicine Faculty, Universitas Indonesia, Jalan Pegangsaan Timur 16, \\ Jakarta 10320, Indonesia
}

\begin{abstract}
The avian influenza A H5N1 outbreaks started in 2003 and Indonesia introduced a vaccination campaign in 2004 to control the disease. In 2007, anecdotal reports about reduced vaccine effectiveness were received from commercial farmers. This paper describes the evolution of viruses in Indonesia up till 2008 and focus on viruses from vaccinating farms reporting vaccine failure were compared to viruses isolated from outbreak areas with no vaccination program. Result of the study revealed that viruses from vaccinated chickens had more extensive mutation at the HA molecule compared to chicken and other avian species without vaccination. Substitutions occurred at the HA gene level as well as at NA, M1 and NS1 genes. Viruses isolated and characterized form 2008 vaccinated flocks had substitutions that were unique and different with the old viruses. The recommendation arising from this study to the avian influenza disease control program in Indonesia is that continuous monitoring of genetic character of viruses and the vaccine seed strain should be updated periodically and matched with the virus circulated in the field.
\end{abstract}

Key words: genetic drift, Indonesia, H5N1 viruses, vaccine

Wabah avian influenza H5N1 terjadi pada tahun 2003 dan pada tahun 2004 Indonesia melaksanakan program vaksinasi massal untuk mengendalikan penyakit ini. Pada tahun 2007 laporan informal tentang ketidakefektifan vaksinasi terutama pada peternakan sektor komersial mulai dijumpai. Penelitian ini menggambarkan evolusi virus avian influenza H5N1 sampai tahun 2008 yang membandingkannya dengan virus yang diisolasi dari peternakan yang mengalami kegagalan vaksinasi dengan virus yang diisolasi dari wabah ayam yang tidak divaksinasi. Hasil dari penelitian ini menunjukkan bahwa virus yang diisolasi dari ayam yang divaksinasi mempunyai mutasi lebih ekstensif dibandingkan dengan ayam yang tidak divaksinasi. Substitusi terjadi pada level gen HA, NA, M1, dan NS1. Virus yang diisolasi dan dikarakterisasi dari flok peternakan ayam yang melakukan vaksinasi mempunyai substitusi yang unik dan berbeda dengan virus sebelumnya. Rekomendasi yang disampaikan dari studi ini untuk mengendalikan penyakit avian influenza di Indonesia ialah memonitoring secara terusmenerus karakter genetika virus AI dan induk galur untuk memproduksi vaksin seharusnya selalu diperbaharui dan disesuaikan dengan virus yang bersirkulasi di lapangan.

Kata kunci:aliran genetika, Indonesia, virus H5N1, vaksin

Influenza viruses are RNA viruses with a negative polarity, included in the Orthomyxoviridae family classified into A, B, and $\mathrm{C}$ types based on the majority of internal protein antigen, i.e. Nucleoprotein (NP) and matrix (M1). Among the three type viruses, influenza virus $\mathrm{A}$ is the most virulent and causes severe and sometimes fatal respiratory diseases. Influenza A virus is classified into several subtypes based on the antigenicity of the two surface proteins, i.e. HA and NA. Viruses that have been identified up till now comprise 16 HA subtypes (H1-H16) and 9 NA subtypes (N1-N9) (Rohm et al. 1996; Fouchier et al. 2005). In Indonesia, the first avian influenza (AI) epidemic was reported in August 2003 in Tangerang Regency and Pekalongan district. The epidemic attacked layer chickens, broiler chickens, indigenous

*Corresponding author, Phone: +62-251-8331048, Fax:+62-251-8336425, E-mail: nlpdharmayanti@gmail.com chickens, and ducks. Based on field examination, the clinical and pathological, the outbreak was diagnosed as the avian influenza subtype H5 (Damayanti et al. 2004). The specimens from the epidemic were successfully isolated and characterized by using a positive avian influenza serum as the avian influenza subtype $\mathrm{H} 5$ virus (Wiyono et al. 2004). Dharmayanti et al.(2004) also identified the outbreak and it was actually caused by AI virus subtype H5 by using RTPCR technique.

The molecular character of AI virus in Indonesia has undergone quite dynamic changes since the occurrence of this disease outbreak in 2003. Genetic analysis show that most of the $\mathrm{H} 5 \mathrm{~N} 1$ influenza viruses from poultry and human in Asia include $Z$ genotype, similar to the virus identified at the first time in poultry in South China (Guan et al. 2004; Li et al. 2004; Puthavathana et al. 2005; WHO 2005). In order to eradicate HPAI from Indonesia, the first priority is to 
reduce the infection and spreading of the disease in poultry. Since the H5N1 outbreak occurred in Indonesia in 2003, Indonesian government has established 9 strategies for controlling the disease i.e. i, bio-security; ii, vaccination; iii, selective depopulation; iv, restriction on traffic of poultry and its product; $\mathrm{v}$, surveillance and tracing back; vi, restocking; vii, stamping out in new infected areas; viii, public awareness; and ix, monitoring and evaluation. As part of the disease control program, the Ministry of Agriculture introduced a vaccination campaign in August 2004. Vaccine was given to various species including layer chickens, broilers, indigenous chicken, ducks, and quails. For the vaccines, Indonesia used both highly pathogenic and low pathogenic avian influenza virus strains. As of December 2008, 20 different AI vaccines have been used to AI disease control in Indonesia.

Previous studies have characterized and reported on the evolution of the Indonesian AI viruses up till March 2007. A study by Takano et al. (2009) suggests that multiple evolutionally distinct lineages of viruses were established in Indonesia, where clade 2.1.3 viruses were increasingly dominating over time compared to clades 2.1.1 and 2.1.2. However, few studies have reported on the impact of the virus evolution on vaccine efficacy or the impact of vaccination on virus drift.

Several field viruses possessing different antigens from the previous $\mathrm{H} 5 \mathrm{~N} 1$ virus based on serological tests using chicken standard sera were also identified in Indonesia and Egypt in 2006 and at the beginning of 2007. These viruses caused mortality of chickens vaccinated with vaccine strains from North America and several seeds of Eurasian strains (Swayne and Kapczynski 2008).

In Indonesia, since vaccination applied to the birds and the $\mathrm{H} 5 \mathrm{~N} 1$ character virus that easily to mutate, this warranted investigation since genetic drift may have occurred in the field virus due to immunological pressure from the vaccination program. Further, an effective vaccine strain should be at least $80 \%$ homologous to the AI field strain (Swayne et al. 1999). This study assesses the evolution of the Indonesian AI viruses up to 2008 and investigated the impact of vaccination. The genetic drift virus that related with using AI vaccination in Indonesia did not yet science reported till now. The study focuses on the characterization of avian influenza viruses that isolated from vaccination flock compared with non-vaccination flock.

In this study, a total of 16 viruses were isolated and characterized to assess the evolution of the AI virus in Indonesia and to assess the difference in virus drift amongst vaccinated birds compared to non-vaccinated birds (Table 1). The 16 viruses were investigated along with publicly available genome datasets of two other Indonesian viruses (A/Ck/WestJava/Pwt-Wij/2006, Acc number EU 124148 and A/Ck/WestJava/Smi-Pat/ 2006, Acc number EU 124160). The viruses were grouped in four groups representing viruses from different years and depending on the originating bird's vaccination status. Group 1 had two isolates that represented viruses from 2006. Group 2 comprised two isolates representing viruses from 2007. Group 3 comprised three isolates from 2008. All isolates in groups 1-3 were from vaccinated birds in breeding or layer farms. Group 4 comprised nine isolates to represent viruses from 2003-2008, where the isolates were from non-vaccinated birds either from layer or backyard farms that experienced laboratory-confirmed AI outbreaks.

\section{MATERIALS AND METHODS}

Specimen Collection and Virus Isolation. Cloacal swab specimens were collected from backyard birds in non-vaccinated outbreak areas and chicken from commercial farms that have been vaccinated birds for a minimum of two years (Table 1).

Sterile cotton-tipped swabs were used for sampling and were subsequently stored in viral transport medium. Transport medium consisted of Dulbecco's modified eagle medium (DMEM) with 1000 IU penicillin and streptomycin. The samples were immediately transported to the laboratory after collection and were stored at $-70^{\circ} \mathrm{C}$. A $1000 \mu \mathrm{L}$ sample in transport medium was homogenized by vortex and centrifuged with the speed of 2500-3000 rpm. The supernatants were then inoculated in embryonated specific pathogen free (SPF) eggs of 9-11 old days obtained from PT. Vaksindo Satwa Nusantara. Allantoic fluid was extracted using QIAmp RNA mini kit (Qiagen, Valencia, CA) according to the manufacturer instructions. The extracted RNA was tested for H5 by RT-PCR using H5-155F and H5-690R primer (Lee et al. 2001). Thermo cycling was performed in ABI 9700 and 2700 PCR machines.

DNA Sequencing and Visualization of 3DProtein Prediction. The $M$ and NS genes were amplified using a primer according to Hoffman et al. (2001). For HA gene, we used sequence primers design by Senne et al. (1996) to amplify HA1 region, and the modification of H5-155F (Lee et al. 2001) and NS890R primers (Hoffmann et al. 2001) was used for HA2. The primers sequence for NA gene were obtained from Komadina N. (private communication 2007 Dec 10). 
Table 1 Avian influenza viruses characterized by year, vaccination status and sample history

\begin{tabular}{|c|c|c|c|c|c|c|}
\hline $\begin{array}{l}\text { Group of } \\
\text { viruses }\end{array}$ & $\begin{array}{c}\text { Year/s of } \\
\text { sample } \\
\text { collection }\end{array}$ & $\begin{array}{l}\text { Virus } \\
\text { number }\end{array}$ & Viruses & Clinical signs & Vaccinated & Sample origin \\
\hline \multirow[t]{2}{*}{1} & \multirow[t]{2}{*}{2006} & 1 & A/Ck/West Java/Pwt-Wij/2006 & $\begin{array}{l}\text { No clinical sign, reduced } \\
\text { egg production }\end{array}$ & Yes & Breeding farm \\
\hline & & 2 & A/Ck/West Java/Smi-Pat/2006 & High mortality & Yes & Breeding farm \\
\hline \multirow[b]{2}{*}{2} & \multirow[b]{2}{*}{2007} & 3 & A/Ck/West Java/Smi-Hj18/2007 & High mortality & Yes & Layer farm \\
\hline & & 4 & A/Ck/West Java/Smi-Sud1/2007 & No clinical sign & Yes & Layer farm \\
\hline \multirow{3}{*}{3} & \multirow{3}{*}{2008} & 5 & A/Ck/West Java/Smi-M1/2008 & High mortality & Yes & Breeding farm \\
\hline & & 6 & A/Ck/West Java/Smi-M6/2008 & High mortality & Yes & Breeding farm \\
\hline & & 7 & A/Ck/West Java/Smi-Biot/2008 & $\begin{array}{l}\text { Reduced egg production, } \\
\text { high mortality }\end{array}$ & Yes & Layer farm \\
\hline \multirow{9}{*}{4} & \multirow{9}{*}{$2003-2008$} & 8 & A/Ck/East Java/BL-IPA/2003 & High mortality & No & Layer farm \\
\hline & & 9 & A/Ck/West Java/1074/2003 & High mortality & No & Layer farm \\
\hline & & 10 & A/Muscovyduck/Jakarta/DKI-Uwit/2004 & High mortality & No & Backyard farm \\
\hline & & 11 & A/Duck/Banten/Pdgl-Kas/2004 & High mortality & No & Backyard farm \\
\hline & & 12 & A/Ck/Jakarta/DKI31/2005 & High mortality & No & Backyard farm \\
\hline & & 13 & A/Muscovyduck/Bgr-Cw/2005 & High mortality & No & Backyard farm \\
\hline & & 14 & A/Ck/West Java/Smi-Hay/2005 & High mortality & No & Backyard farm \\
\hline & & 15 & A/Ck/West Java/Smi-Acul/2008 & High mortality & No & Backyard farm \\
\hline & & 16 & A/Ck/Banten/Srg-Fadh/2008 & High mortality & No & Backyard farm \\
\hline
\end{tabular}

The GenBank/EMBL/DDBJ accession numbers for the sequences reported in this paper are A/Ck/East Java/BL-IPA/2003 (GU183447, GU183466, GU183427, GU183407), A/Ck/West Java/1074/2003 (GU183448, GU183467, GU183428, GU183408); A/Muscovyduck/Jakarta/DKI-Uwit/2004 (GU183449, GU183468, GU183429, GU183409); A/Duck/Banten/Pdgl-Kas/2004 (GU183450, GU183470, GU183430, GU183410); A/Ck/Jakarta/DKI31/2005 (GU183451, GU183469, GU183431, GU183411); A/Muscovyduck/Bgr-Cw/2005 (GU183452, GU183485, GU183432, GU183412); A/Ck/West Java/Smi-Hay/2005 (GU189678, Gu183471, GU183433, GU183413); A/Ck/West Java/Smi-Hj18/2007 (GU183459, GU183478, GU183440, GU183420); A/Ck/West Java/Smi-Sud1/2007 (GU183460, GU183479, GU183441, GU183421); A/Ck/West Java/Smi-Acul/2008 (GU183465, GU183480, GU183442, GU183422); A/Ck/Banten/Srg-Fadh/2008 (GU183461, GU183481, GU183443, Gu183423); A/Ck/West Java/Smi-M1/2008 (GU183462, GU183482, GU183444, GU183424); A/Ck/West Java/Smi-M6/2008 (GU183463, GU183483, GU183445, Gu183425); A/Ck/West Java/SmiBiot/2008 (GU183464, GU183484, GU183446, Gu183426).

Sequencing was performed by BigDye Terminator V3.1 cycle sequencing kit on Genetyx Analyzer 3130 (Applied Biosystems, USA). All sequence segments were assembled and aligned by BioEdit, version 7 (http://www.mbio.ncsu.edu/BioEdit). Phylogenetic trees were generated by neighbor-joining bootstrap analysis (1000 replicates) using the Kimura twoparameter model in MEGA, version 4 (http://www. megasoftware.net).

Visualization of predicted 3D-protein was conducted using the sequence produced from amino acid translation at HA1, NA, M1 and NS1 proteins. BLAST search (DS server) was used to locate the template with the highest homology. Multiple sequences were aligned and a 3D-model was built using DS Modeler and DS Standalone from Discovery Studio for Modeling and Simulation (Accelrys Discovery Studio version 2.1) (Dharmayanti 2009).

\section{RESULTS}

Analysis on the HA, NA, M, and NS Proteins. The phylogenetic analysis of HA gene shows that viruses from vaccinated chickens formed a different group compared to the viruses isolated from nonvaccinated birds and even humans in Indonesia (Fig 1a). Further, viruses from vaccinated chickens in 2007 2008 formed a different group to viruses from vaccinated chickens in 2006.

For the HA gene, viruses characterized in this study had 5-8 glycosylation sites. Only three viruses had 8 glycosylation sites and all were from nonvaccinated birds (Group 4). Most viruses did not have glycosylation site at position 84 and vaccinated chicken viruses possessed only five glycosylations sites (Fig 2).

For the NA and NS1 genes, the viruses from vaccinated chickens had a specific difference in the amino acid substitutions of NA protein compared to those in other Indonesian viruses. The overall difference from the original 2003 strain (A/East Java/BLIPA/03) was only $1.3-2 \%$. At the NA protein, the viruses from vaccinated chicken from 2007-2008 had an amino acid substitution at position T76N. The 2008 vaccinated chicken virus had substitutions of P74S and T289I, which were even absent in the 2007 vaccinated chicken viruses (Table 2).

The phylogenetic analysis of the M1 gene showed that viruses from vaccinated chickens were in the same group as viruses isolated from human cases in Indonesia (Fig 1c), where they all held amino acid 
substitutions at positions T37A, R95K, T137A, and Q249H. Viruses from vaccinated chickens differed from other animal Indonesian viruses in that they had a T167N substitution (Fig 3).

There were three substitutions in NS1 protein of viruses from 2007-2008 vaccinated chickens; V136L, T197A, and L212P, except the A/Ck/West Java/SmiM6/08 virus did not have the substitution of T197A. Viruses from 2008 vaccinated chickens also had a unique substitution in NS1 protein (F22L) (Fig 4, Table 2).
Antigenic Drift at HA gene. Compared to one of the earliest $\mathrm{H} 5 \mathrm{~N} 1$ viruses isolated in Indonesia in 2003 (A/East Java/BL-IPA/03), most mutations occurred in viruses from vaccinated chickens (Groups 1,2 , and 3) rather than viruses from non-vaccinated chickens isolated during similar timeframes and locations (Group 4). Group 1 had $4.95 \%$ amino acid differences to the 2003 virus, Group 2 had $6.70 \%$ amino acid differences and Group 3 had $7.71 \%$ amino acid differences a total of 41 to 43 mutations in this Group. Even though unvaccinated chickens (Group 4)

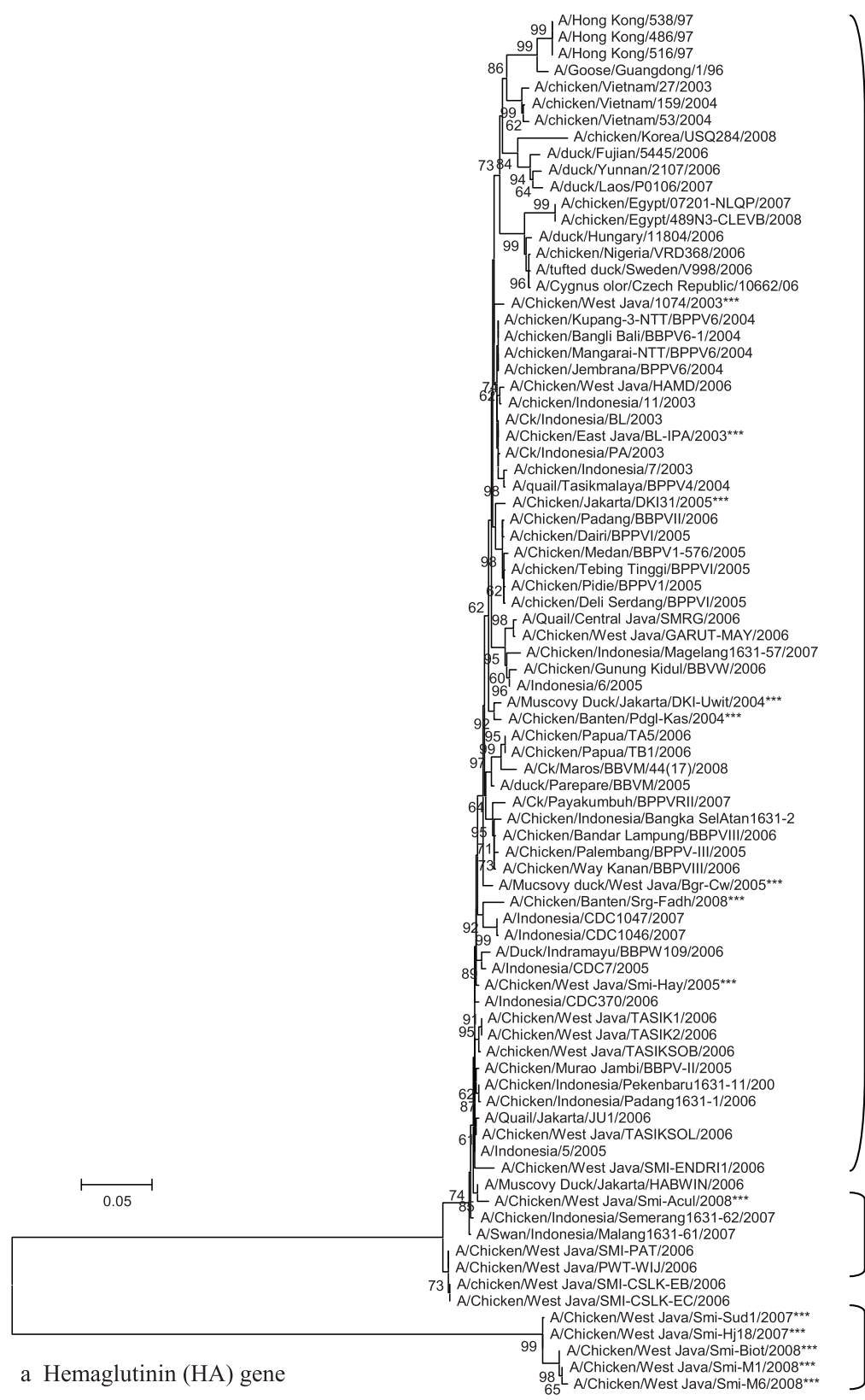

Non-vaccinated

group isolates
Antigenic drift viruses 2006

Vaccinated group isolates (antigenic drift viruses 2007-2008)

Fig 1 The phylogenetic tree of HAI, NA, MI, and NSI genes. a, Phylogeneticrelationships of the HA1 domain of the haemagglutinin (HA); b, Neuraminidase (NA); c, Matrix 1 (M1), and d, Non-structural (NS1) gene of the H5N1 viruses isolated from AI vaccination flock and AI H5N1 viruses $2003-2008$ in Indonesia (stars sign). The region of the haemagglutinin from HA1 49-1680. Neuraminidase from N1-1157. Matrix from 1- 759 and non-structural from 1-690 have been analyzed using MEGA version 4. Aneighbor-joining bootstrap analysis (1000 replicates) using the Kimura-Nei model is shown. 


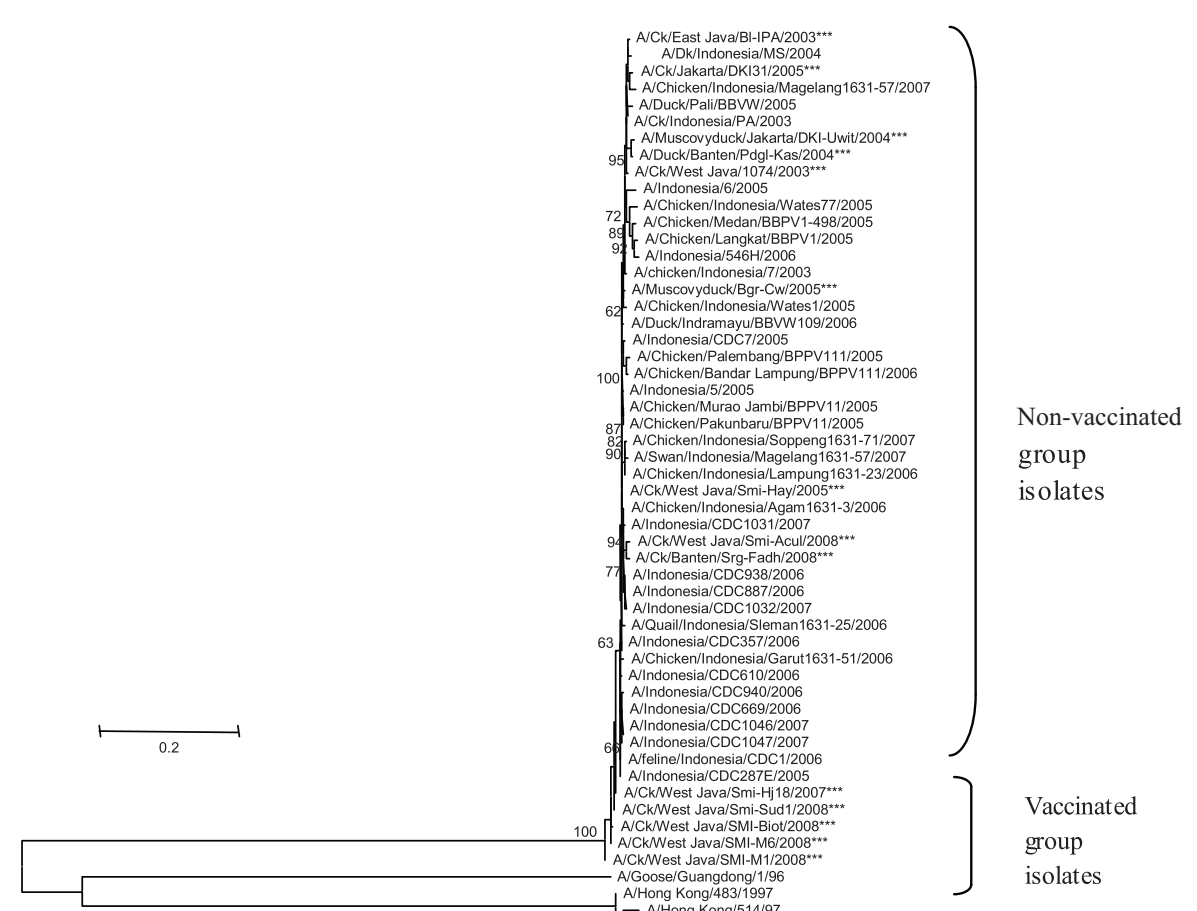

b Nuraminidase (NA)

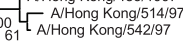

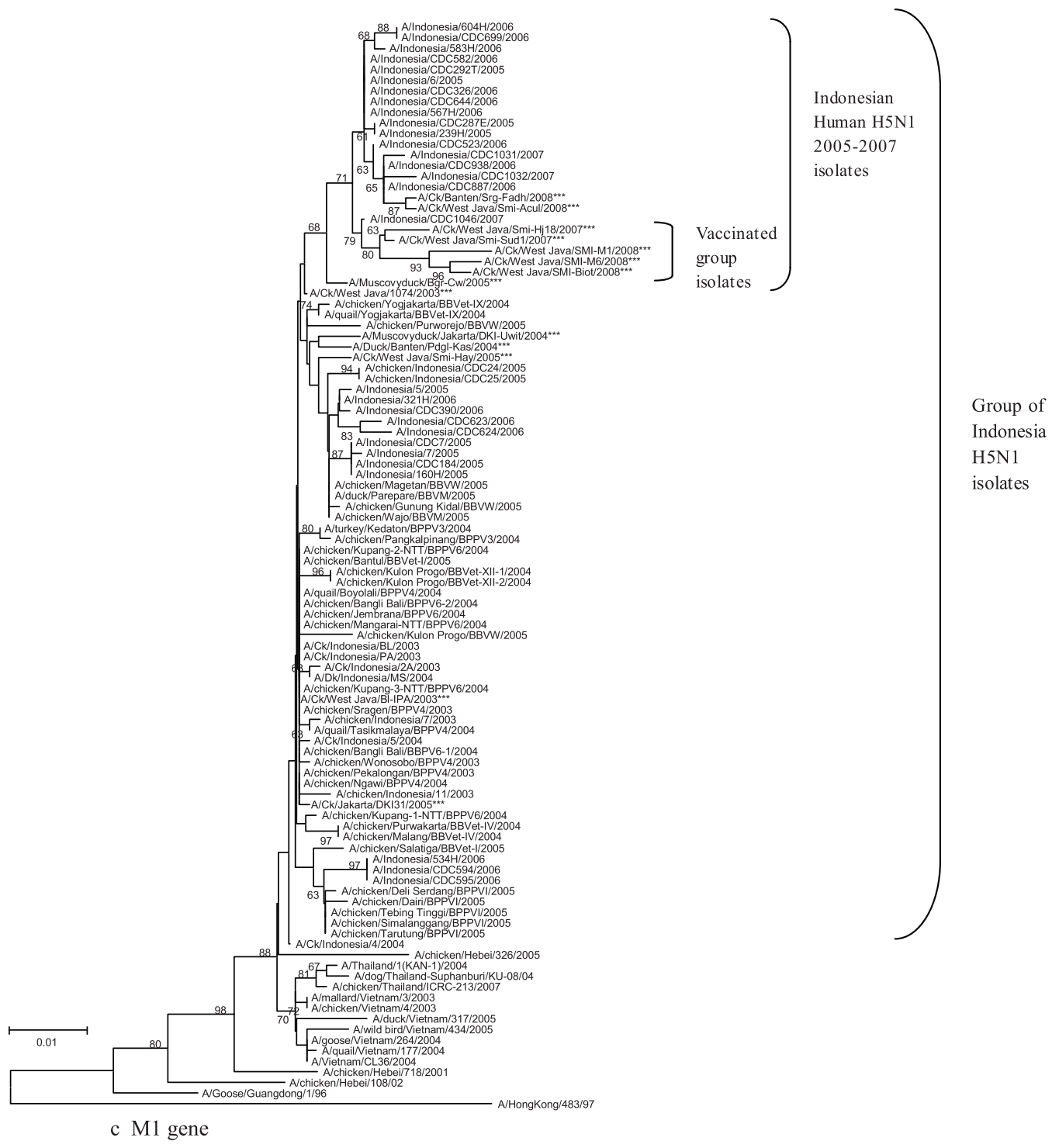

Fig 1 (continued) 


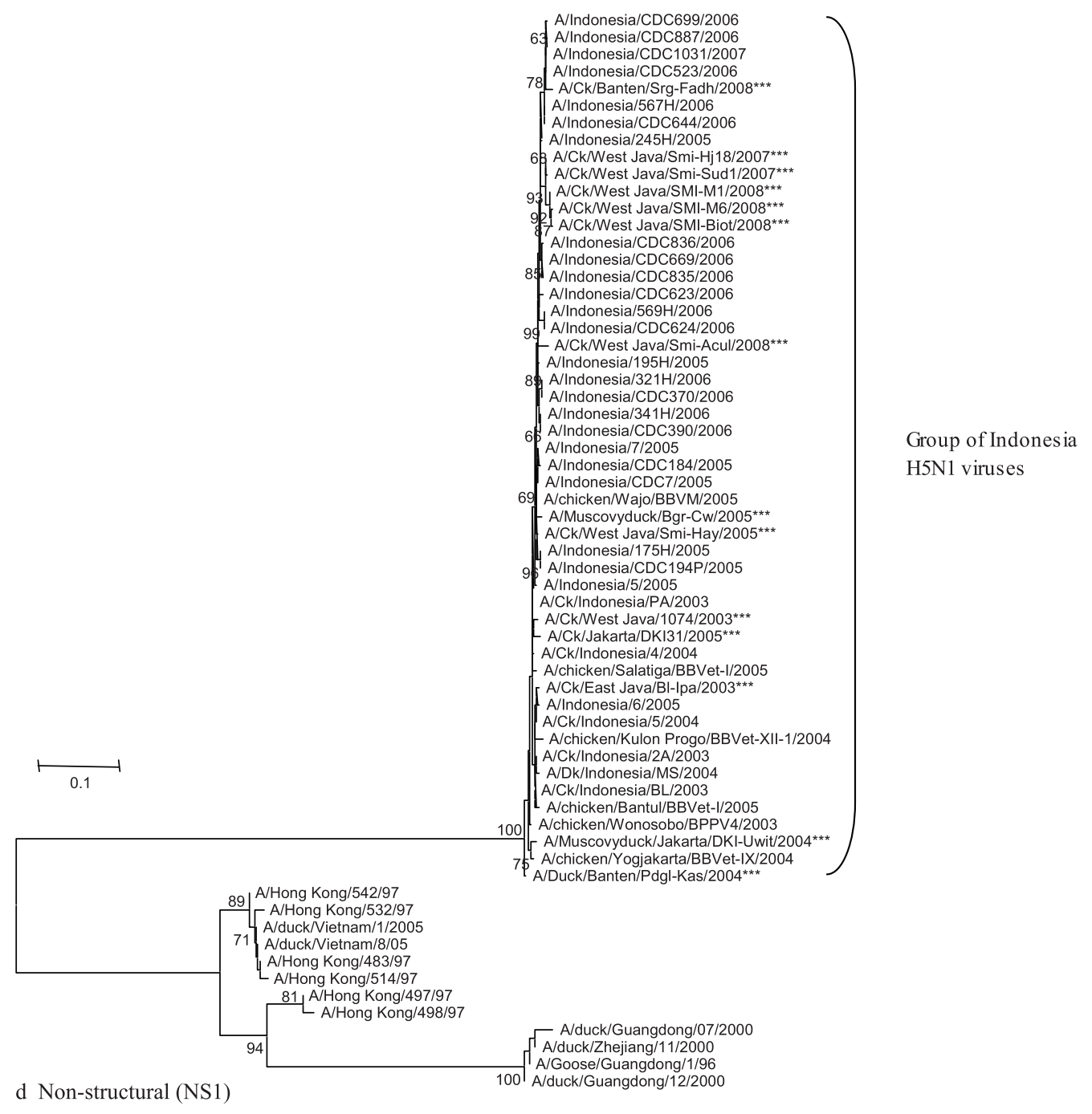

Fig 1 (continued)

also underwent mutations, this occurred at a slower rate. By 2008, these viruses had a total of $2-3 \%$ mutations.

Compared to the 2003 virus, the HA gene from viruses from vaccinated chickens had 18 specific amino acid substitutions (Fig 2). Mutations continued in 2007 compared to 2006 and there were further mutations only seen in 2008 vaccinated chickens (Table 2).

The drift over the five year period can be seen in corresponding decreased vaccine strain homology. Up till 2007, there was $83-89 \%$ homology with the 2003 vaccine strain and other imported vaccine strains. By 2008 , the homology of Group 3 viruses to vaccine strains reduced to $76-77 \%$. These 2008 field viruses had only slightly better homology to H5N2 vaccine strains (Mex/232/94, Wisconsin/68 and N28/73) at $81 \%$ (data not shown).

Based on the visualization of 3D prediction, it can be seen that the mutation in the virus from vaccinated chickens mostly occurred on the surface of HA molecule (Fig 5). This globular head domain of HA1 protein is the target of the host antibody. Further, the virus from the Group 3 (Fig 4) appeared different from the viruses from Group 1 and 2, where they possessed more amino acid on the surface of the molecule including proline, lysine, and serine at position 123 , 188 , and 189 respectively.

\section{DISCUSSION}

Antigenic drift is a gradual evolution of the viral strain, due to frequent mutation (Both et al. 1983). In human, this happens at the average of 2-8 years as a response from the selection pressure to avoid the human immunity (Plotkin et al. 2002; Smith et al. 2004; Koelle et al. 2006). The antigenic drift process including the point mutation in the antibody binding site in HA or NA protein or both occurs every time the virus carries out replication (Swayne and Kapczynski 2008). Most of these mutations have no effects or 

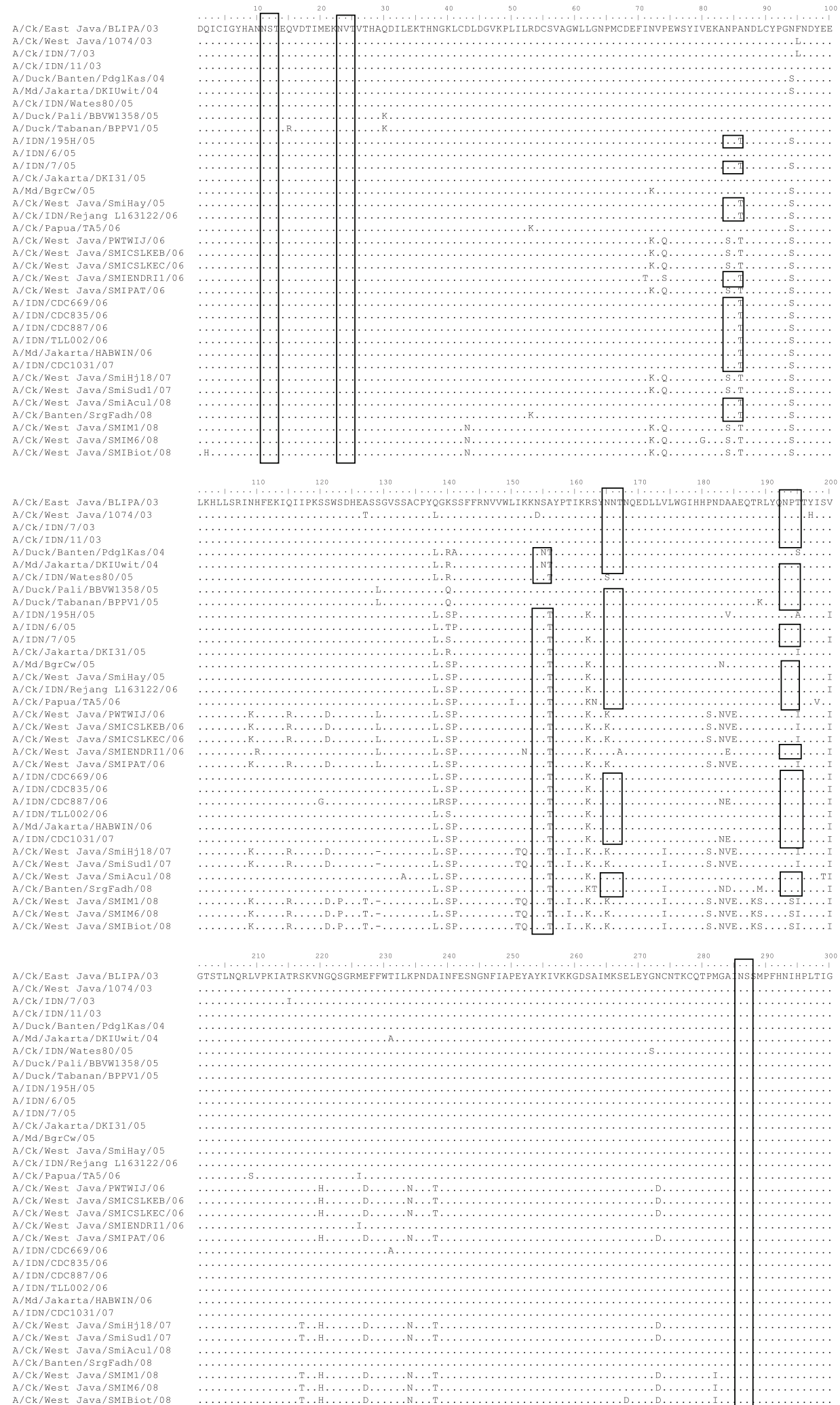

Fig 2 Alignment of the predicted amino acid sequences of the HA protein. Glycosylation sites are showed by boxes. * Residues involved the cleavage site on HA. 
A/CK/East Java/BLIPA/03
A/CK/West Java/1074/03 $\mathrm{A} / \mathrm{CK} / \mathrm{IDN} / 7 / 03$

$\mathrm{A} / \mathrm{CK} / \mathrm{IDN} / 11 / 0$

/Duck/Banten/Pdg1Kas/04 /CK/IDN/Wates80/05 A/Duck/Pa11/BBVW1358/05 (a) $\mathrm{A} / \mathrm{IDN} / 6 / 05$

A/DNN/7/705

A/CK/Jakarta/DKL 31/0

A/CK/West Java/Smi Hay/0 A/CK/IDN/Rejang L163122/0 A/CK/West Java/PWTWIJ/0

/Ck/West Java/SMICSLKEB/ A/CK/hest Java/SMICSLREC/ /CK/West Java/SMT PAT/06 A/IDN/CDC669/06
A/IDN/CDC835/06

A/IDN/CDC835/06
A/DN/CDC887/06

A/TDN/TLLD D002/06

A/Md/Jakarta/HABwIN/O6

A/IDN/CDC1031/07

a/Ck/West Java/sminj $18 / 07$

A/Ck/West Java/SmiAcul/0

A/CK/Vest Jaya/5MTM1/08 A/Ck/West Java/SMIMG/08 A/Ck/West Java/SMIBiot/

A/CK/East Java/BLIPA/03

$\mathrm{A} / \mathrm{CK} / \mathrm{IDN} / 7 / 03$
$\mathrm{~N} / \mathrm{CK} / \mathrm{IDN} / 11 / 0$

H/Duck/Banten/Pdg1Kas/0

/Md/Jakarta/DRIUwit/04

A/Duck/Pali/BBWW1358/05

/Duck/Tabanan/BPPV1/05

A/IDN/195H/O5

A/IDN/7/05

A/Ck/Jakarta/DKI31/05

$/ \mathrm{Md} / \mathrm{BgrCW} / 0$

源 /CK/Papua/TAS/06

Wk/west Java/PNITIJ/06

/CK/West Java/SMICSLKEC/06

/Ck/West Java/SMIENDRI1//6

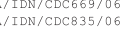

/IIDN/CDC887/06

A/Md/Jakarta/HABWIN/06

A/IDN/CDC1031/07

A/Ck/West Java/SmiHj18/07

/Ck/West Java/Smincul/ 08

A/Ck/Banten/SrgFadh/08

A/Ck/west Java/SMIM1708

A/Ck/west Java/SMIBiot/o

A/CK/East Java/BLIPA/03

$\mathrm{A} / \mathrm{CK} /$ West Java/
$\mathrm{A} / \mathrm{CK} / \mathrm{IDN} / 7 / 03$

Huck/Banten/Pdglkas/04

/Md/Jakarta/DKIUwit/04

A/CR/IDN/Wates $80 / 05$

A/Duck/Tabanan/BPpV1/05

A/IDN/195H/05

A/TDN/6705

A/Ck/Jakarta/DKI31/05

$\mathrm{A} / \mathrm{Md} / \mathrm{BgrCW} / 05$

A/CK/West Java/smi Hay/05

A/Ck/Papua/TA5/06

A/CK/West Java/PWTWIJ/06

A/Ck/nest Java/ SMICSLKEB/

h/Ck/West Java/SMIENDRI

/Ck/West Java/sMIPAT/O

ATIDN/CDC835/06

A/IDN/CDC887/06

A/IDN/TIL002/06

A/Md/Jakarta/HABNIN/O
A/IDN/CDC1031/07

A/Ck/West Java/SmiHj18/0

A/CK/West Java/Smisud1/07

/CK/West Java/SMiM1/0

ACK/West Java/SMIM6/08

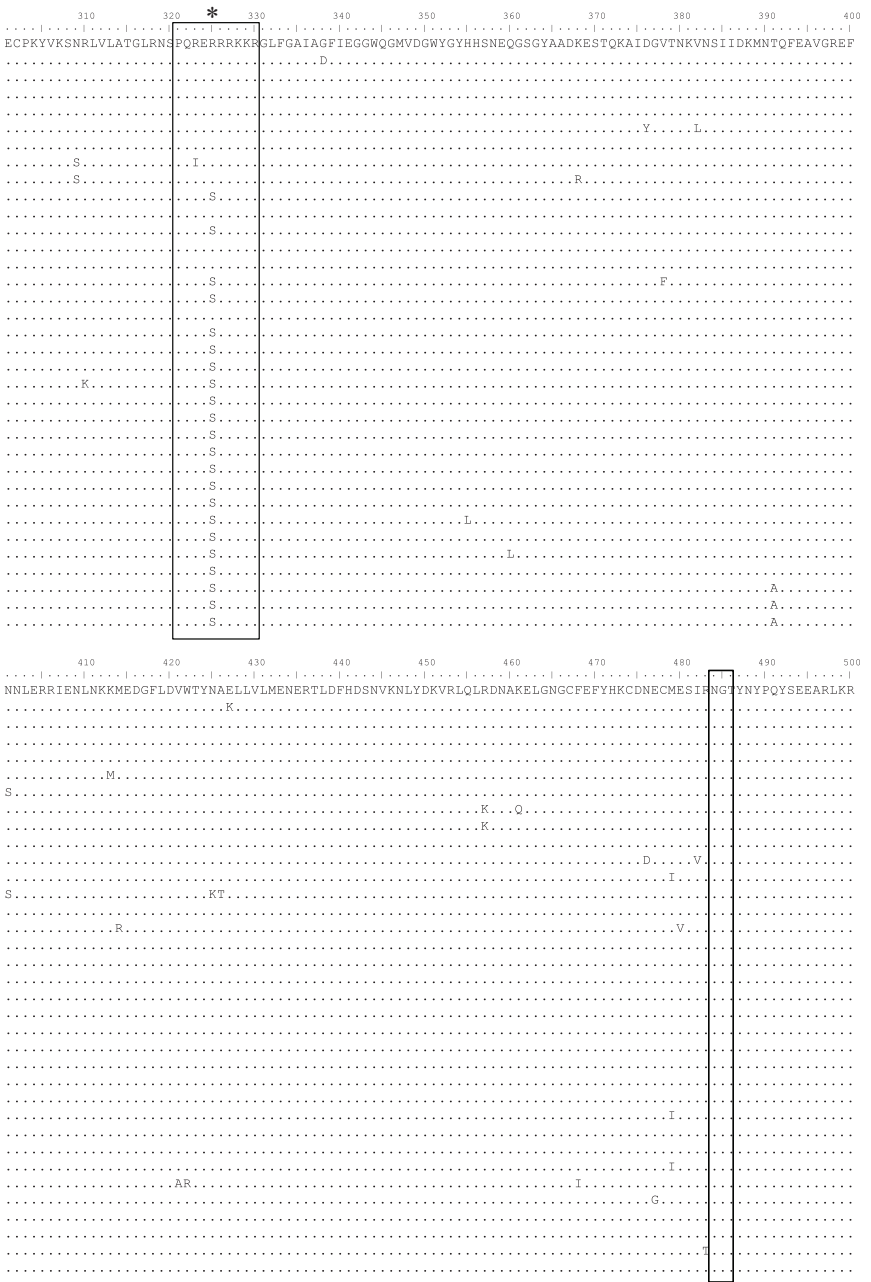

EISGVKLESIGTYQI LS IYSTVASSLALA IMMAGLSLWMCSNG-

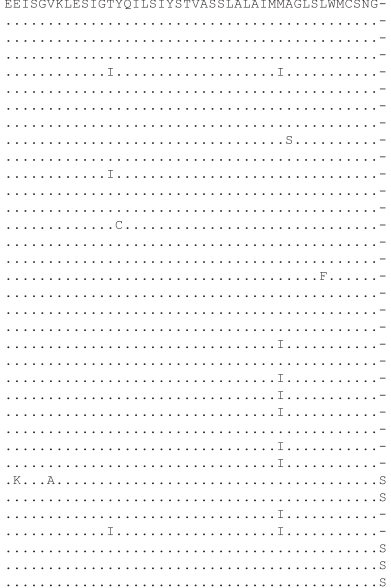

Fig 2 (continued). 
Table 2 Mutation of viruses from vaccinated chickens compared with A/Ck/East Java/BL-IPA/03

\begin{tabular}{lcc}
\hline \multirow{2}{*}{ Group of viruses } & HA & Mutation in genes \\
\cline { 2 - 3 } & N72K, P74Q, N84S, A86T, N109K, Q115R, S121D, & NA \\
\hline Vaccinated chickens & N165K, P181S, D183N, A184V, A185E, T195I, & none* \\
2006-2008 & N220H, E257D, P235N, I239T, N273D & T76N \\
(Group 1-3) & Deletion of position129, and substitution of I151T, K152Q, & none* \\
Vaccinated chickens & T159I, V174I, S217T. & T167N \\
2007-2008 (Group 2) & D43N, S123P, E127T, T188K, R189S, P193S, & P74S, T289I \\
Vaccinated Chickens & M282I, T391A & none \\
2008 (Group 3) & F22L
\end{tabular}

*Data unavailable for 2006 vaccinated chickens viruses

neutral as these do not influence the protein confirmation although several mutations can cause changes in virus protein, such as the binding of host antibodies. Consequently, the infecting virus cannot be inhibited effectively by the host antibodies, thus the virus can spread more quickly in a population. Dharmayanti et al. (2010) showed that during 20032008 , around $62.58 \%$ of Indonesian influenza H5N1 subtype had resistance to amantadine.

The antigenic drift occurs in all strains of A and B viruses, though the evolution forms vary depending on the strains. For the influenza virus A (H1) and B, variants drift usually happen co-circulation with multiple co-existing lineages, followed by the reemergence of old isolates. In the influenza A subtype $\mathrm{H} 3$ virus more frequently mutates and forms a new variant replacing the old strain (Swayne and Kapczynski 2008). Result of our study showed that the Indonesian viruses isolated from vaccinated farms had more mutations and antigenic drift compared to viruses from non-vaccinated birds. The mutations occurred at the HA, NA, M1, and NS1 protein level even though the highest mutations at the HA protein. On 2008 viruses from vaccinated birds formed a distinct group, sufficiently different from both human AI viruses and viruses from non-vaccinated birds. The impact of these changes on disease in birds and potential transmission to humans is not yet understood.

The visualization of $3 \mathrm{D}$ prediction shows the difference between viruses Pwt-Wij/2006 and SmiM6/2008 about 14 amino acids residue including 3 amino acids on the surface of the molecule, thus it can understood that this may cause the vaccine seed of virus Pwt-Wij/2006 could not protect the SmiM6/2008 virus. The HA1 domain of hemagglutinin (HA) is a very important antigenic protein in the influenza A virus containing all HA antigenic sites that determines the identification of the host immune system (Shih et al. 2007). Changes in this domain will influence the host immune response. From the unpublished data in our laboratory, we used the A/Chicken/West Java/Pwt-Wij/2006 as a master seed vaccine against the $\mathrm{A} /$ Chicken/West Java/SmiM6/2008 (Group 3) as a challenge virus. The result showed that the vaccine cannot fully protective the virus and shedding virus occurred more than 14 days.

Most viruses isolated from vaccinating farms had reduced glycosylation sites compared to viruses from non-vaccinated birds. A reduction in these sites can result in a virus population with increased receptor affinity or a virus population that is more resistant to neutralization than the parental virus (Schulze 1997).

Both the visualization of $3 \mathrm{D}$ prediction in this study and the challenge test in our unpublished study provide evidence for this outcome in the Indonesian virus, where 2008 virus from vaccinating farms (A/West Java/Smi-M6/08) was not neutralized by the 2006 vaccine strain virus (A/West Java/Pwt-Wij/06). The antigenic drift is the gradual evolution of the viral strain. The antigenic drift process can occur every time the virus carries out replication, affecting the antibody binding site in HA, NA protein or both (Shih et al. 2007). Most of the mutations have no effect and do not influence the protein confirmation. However, some mutations can cause changes in virus protein such as the binding of host antibodies. If this occurs, the infecting virus cannot be inhibited effectively by the host antibodies, allowing the virus to replicate further and potentially spread more quickly in a population. This study lends further evidence that the vaccination campaign in Indonesian farms led to more rapid antigenic drift of the virus.

The recommendation arising from this study to the AI disease control program in Indonesia is that the seed strain for vaccine needs to be updated beyond 2006 . This is a major undertaking considering the antigenic 
A/CK/IDN/7/2003

$\mathrm{A} / \mathrm{Ck} / \mathrm{Sragen} / \mathrm{BPPV} 4 / 2003$

${ }_{\mathrm{A} / \mathrm{Ck} / \mathrm{Y} \text { ogjakarta/BBVetIX/2004 }}$

A/Cl/Yogjakarta/BBVetIX/2004
A/Dk/IDN/MS/2004

A/CK/Kupang3NTT/BPPV6/2004

A/CK/NGawi/BPPV4/2004
A/Ck/Purwakarta/BBVetIV/2004

A/CK/Purwakarta/BBVetIV/2004
A/Md/Jakarta/DKIUwit/2004
A/Duck/Banten/Pdg1Kas/2004

A/Ck/Jakarta/DKI31/2005

$\mathrm{A} / \mathrm{Md} / \mathrm{BgrCw} / 2005$

A/Ck/Mest Java/SmiHay/2005

$\mathrm{A} / \mathrm{CK} / \mathrm{IDN} / \mathrm{CDC} 24 / 200$

/Ck/Purworejo/BBVW/200

A/IDN/5/2005

A/IDN/CDC887/2006

AIIDN/CDC1031/2007

A/IDN/CDC1032/2007

A/IDN/CDC1046/2007

A/Ck/West Java/SmiHj18/2007

/Ck/Banten/SrgFadh/2008

A/Ck/West Java/SmiAcul/200

$\mathrm{A} / \mathrm{Ck} /$ West Java/SMIM1/2008

A/Ck/West Java/SMIM6/2008

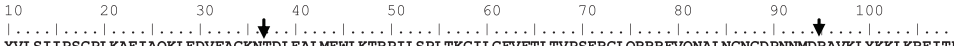

A/Ck/West Java/BlIPA/2003 $\mathrm{A} / \mathrm{CK} / \mathrm{IDN} / 11 / 2003$

A/Ck/West Java/1074/2003

A/Ck/Sragen/BPPV4/2003

A/Ck/Yogjakarta/BBVetIX/2004

A/Dk/IDN/MS/2004
A/Ck/Kupang3NTT/BPPV6/2004

A/Ck/Kupang3NTT/BPPV6/2004

A/Ck/Purwakarta/BBVetIV/2004

A/Duck/Banten/Pdg1Kas/200

A/CK/Jakarta/DKI 31/2005

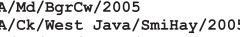

A/CK/IDN/CDC24/2005

A/Ck/Pusworejo/BBVW/2005

A/IDN/5/2005

AIDN/CDC938/2006

A/IDN/CDC1031/2007

A/IDN/CDC1032/2007

/Ck/West Java/SmiHj18/2007

/Ck/West Java/SmiSud1/2007

$\mathrm{A} / \mathrm{Ck} /$ Banten/SrgFadh/2008

/Ck/West Java/SmiAcul/2008

/Ck/West Java/SMIM6/2008

A/CK/West Java/SMIBiot/2008

YVLSIIPSGPLKAEIAQKLEDVFAGKNTDLEALMENLKTRPILSPLTKGILGFVFTLTVPSERGLQRRRFVQNALNGNGDPNNMDRAVKLYKKLKREITF
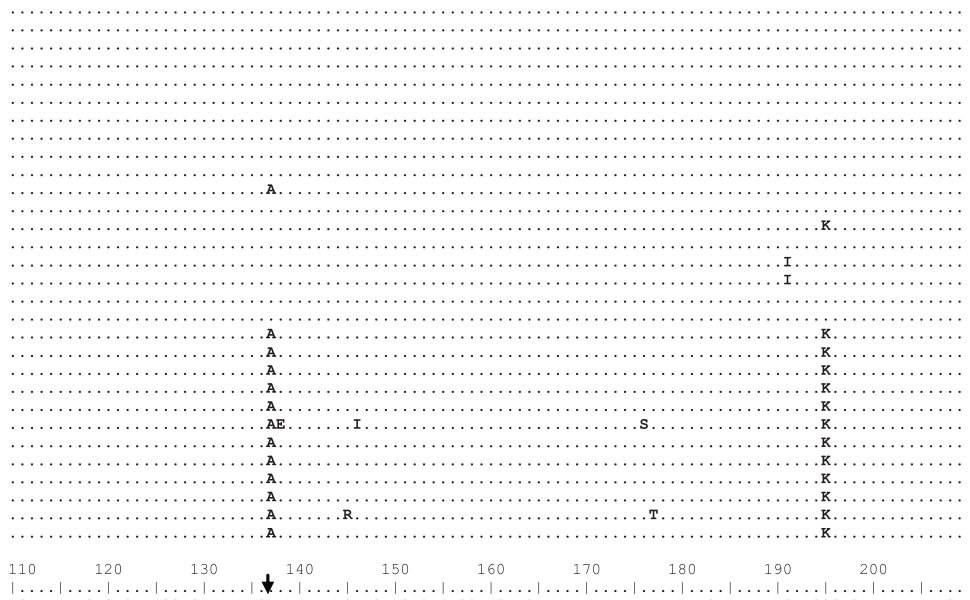

HGAKEVALSYSTGALASCMGLYYNRMGTVTTEVAFGIVCATCEQIADSQHRSHRQMATITNDIIRHENRMVLASTTAKAMEQMAGSSEQAAEAMEVANQA
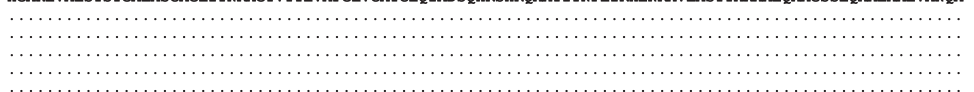

A/Ck/West Java/BlIPA/2003

$\mathrm{A} / \mathrm{CK} / \mathrm{IDN} / 11 / 2003$
$\mathrm{~A} / \mathrm{Ck} / \mathrm{IDN} / 7 / 2003$

A/Ck/IDN $/ 7 / 2003$
A/Ck/West Java $/ 1074 / 2003$

A/Ck/West Java/1074/2003
A/Ck/Sragen/BPPV4/2003

A A CK/TDN/2A/2003
A/Ck/Yogjakarta/BBVetIX/2004

$\mathrm{A} / \mathrm{Dk} / \mathrm{IDN} / \mathrm{MS} / 2004$

A/Ck/Kupang3NTT/BPPV6/2004

A/Ck/Purwakarta/BBVetIV/2004

A/Md/Jakarta/DKIUwit/2004
A/Duck/Banten/Pdg1Kas/2004

A/Duck/Banten/PdglKas/2004

A/Ck/Jakarta/DKs

/Ck/West Java/SmiHay/2005

$\mathrm{A} / \mathrm{CK} / \mathrm{IDN} / \mathrm{JDC} 24 / 2005$

A/CK/IDN/CDC25/2005

A/Ck/Purwore

A/IDN/CDC887/2006

A/IDN/CDC938/2006

A/IDN/CDC1031/2007

$\mathrm{A} / \mathrm{IDN} / \mathrm{CDC} 1046 / 2007$

A/Ck/West Java/SmiHj18/2007

$\mathrm{A} / \mathrm{Ck} /$ West Java/SmiSud1/2007

$\mathrm{A} / \mathrm{Ck} / \mathrm{Banten} / \mathrm{SrgFadh} / 2008$

A/Ck/West Java/SMIM1/2008

A/Ck/West Java/SMTM6/2008

A/Ck/West Java/SMIBiot/2008
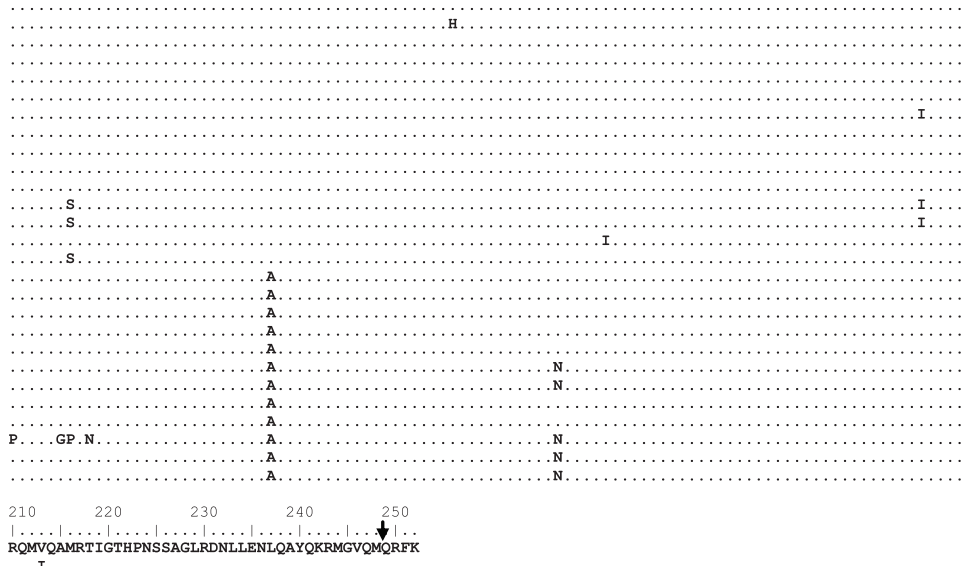

QMVQAMRTIGTHPNSSAGLRDNLLENLQAYQKRMGVQMQRFK

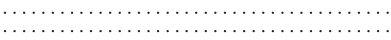

.

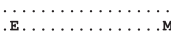
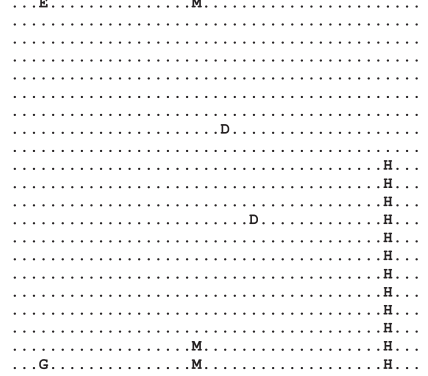

Fig 3 Alignment of the predicted amino acid sequences of the M1 protein. The amino acid substitutions were showed with the arrow mark. 

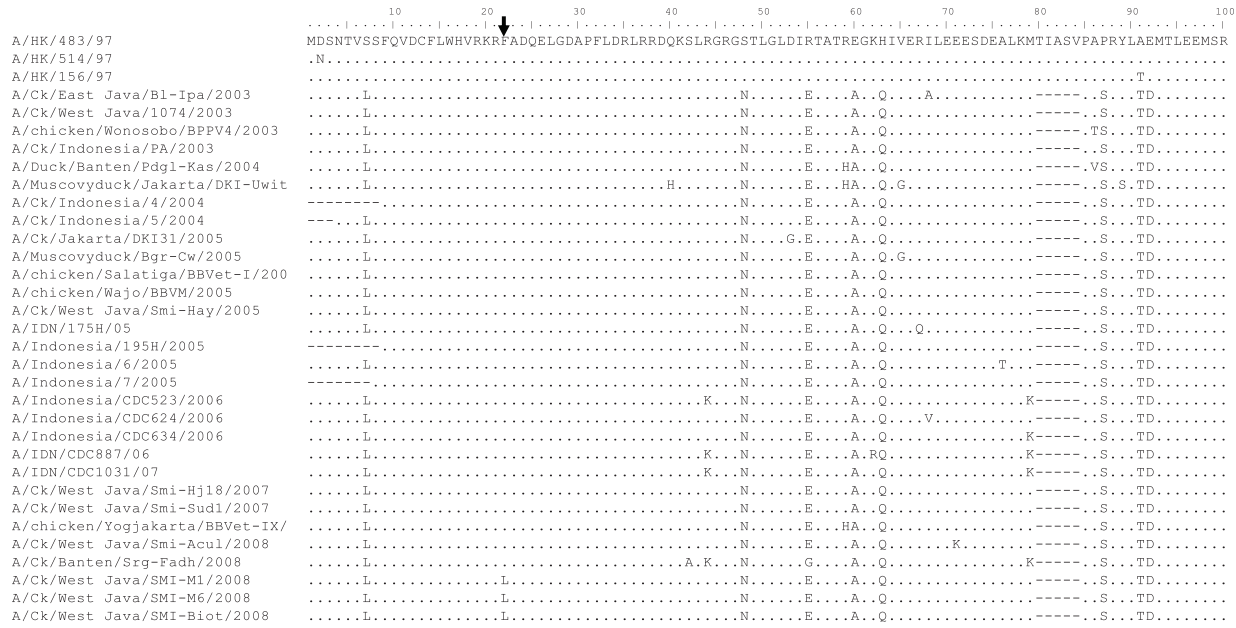

$\mathrm{A} / \mathrm{HK} / 483 / 97$
$\mathrm{~A} / \mathrm{HK} / 514 / 97$

A/CK/East Java/B1-Ipa/2003

A/CK/West Java/1074/2003

A/chicken/Wonosobo/BPPV4/2003

A/CK/Indonesia/PA/2003

A/Muck/Banten/Pdg1-Kas/2004

A/Ck/Indonesia/4/2004

A/CK/Indonesia/5/2004
A/CK/Jakarta/DKI $31 / 2005$

A/Muscovyduck/Bgr-Cu/2005

A/chicken/salatiga/BBVet-I/200

A/chicken/Wajo/BBVM/2005

A/Ck/West Java/Smi-Hay/2005

A/Indonesial1 $95 \mathrm{H} / 2005$

A/Indonesia/6/2005

A/Indonesia/7/2005

A/Indonesia/CDC523/2006

A/Indonesia/CDC634/2006

$\mathrm{A} / \mathrm{IDN} / \mathrm{CDC} 887 / 06$
$\mathrm{R} / \mathrm{IDN} / \mathrm{CDC1031/07}$

A/IDN/CDC1031/07
A/CK/West. Java/Smi-Hj 18/2007
A/CK/West Java/Smi-Sud1/2007

A/chicken/Yogjakarta/BBVet-IX/
A/Ck/West Java/Smi-Acul/2008

A/Ck/Banten/Srg-Fadh/2008

$\mathrm{A} / \mathrm{Ck} /$ West Java/SMI-M1/2008
$\mathrm{A} / \mathrm{Ck} /$ West Java/SMI-M6/2008

A/CK/West Java/SMI-M6/2008
A/CK/West Java/SMI-Biot/2008

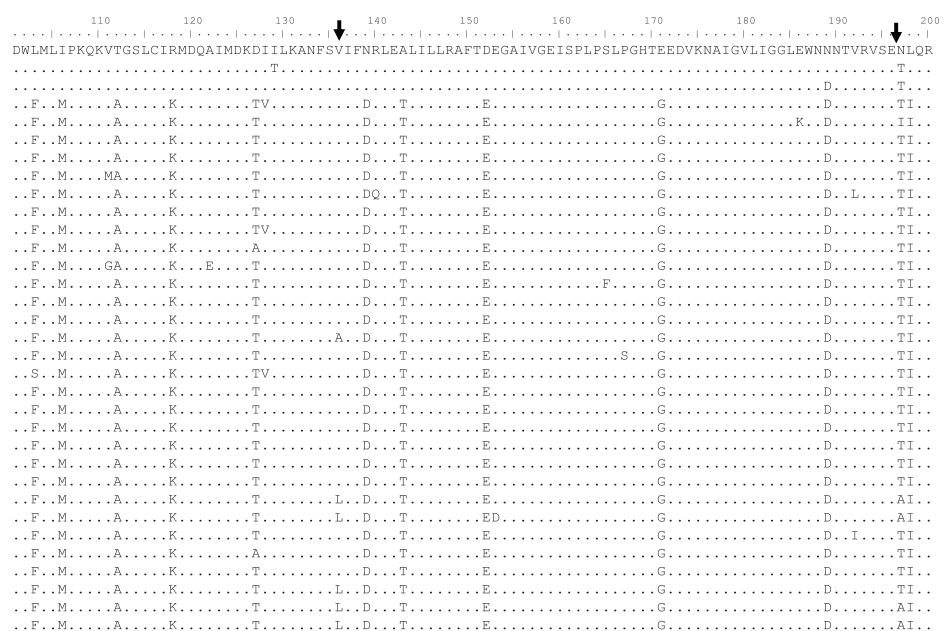

$\mathrm{A} / \mathrm{HK} / 483 / 97$
$\mathrm{~A} / \mathrm{HK} / 514 / 97$
$\mathrm{~A} / \mathrm{HK} / 156 / 97$

A/Ck/East Java/B1-Ipa/2003

A/chicken/Wonosobo/BPPV4/200

A/CK/Indonesia/PA/2003

A/Duck/Banten/Pag1-Kas/2004

A/Muscovyduck/Jakarta/D
A/Ck/Indonesia/4/2004

A/CK/Indonesia/5/2004

A/Ck/Jakarta/DRI31/2005
A/Muscovyduck/Bgr-Cw/2005

A/Muscovyduck/Bgr-CW/2005

A/chicken/Wajo/BBVM/2005

A/Ck/West Java/Smi-Hay/2005

A/IDN/175H/05

A/Indonesia/195H/200
A/Indonesia/6/2005

A/Indonesia/7/2005

A/Indonesia/CDC523/2006

A/Indonesia/DDC624/2006

A/IDN/CDC887/06

A/IDN/CDC1031/07

A/CK/West Java/Smi-Hj18/2007

A/chickes/rogjaka

$\mathrm{A} / \mathrm{Ck} /$ West Java/Smi-Acu1/2008

A/Ck/Banten/Srg-Fadh/2008

A/CK/West Java/SMI-M1/2008
A/CK/West Java/SMI-M6/2008

A/CK/West Java/SMI-M6/2008
A/CK/West Java/SMI-Biot/2008

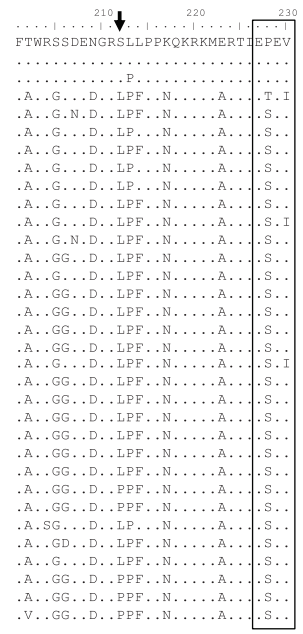

Fig 4 Alignment of the predicted amino acid sequences of the NS1 protein. PDZ ligand motif were showed with amino acid sequence in the box. The amino acid substitutions were showed with the arrow mark. 

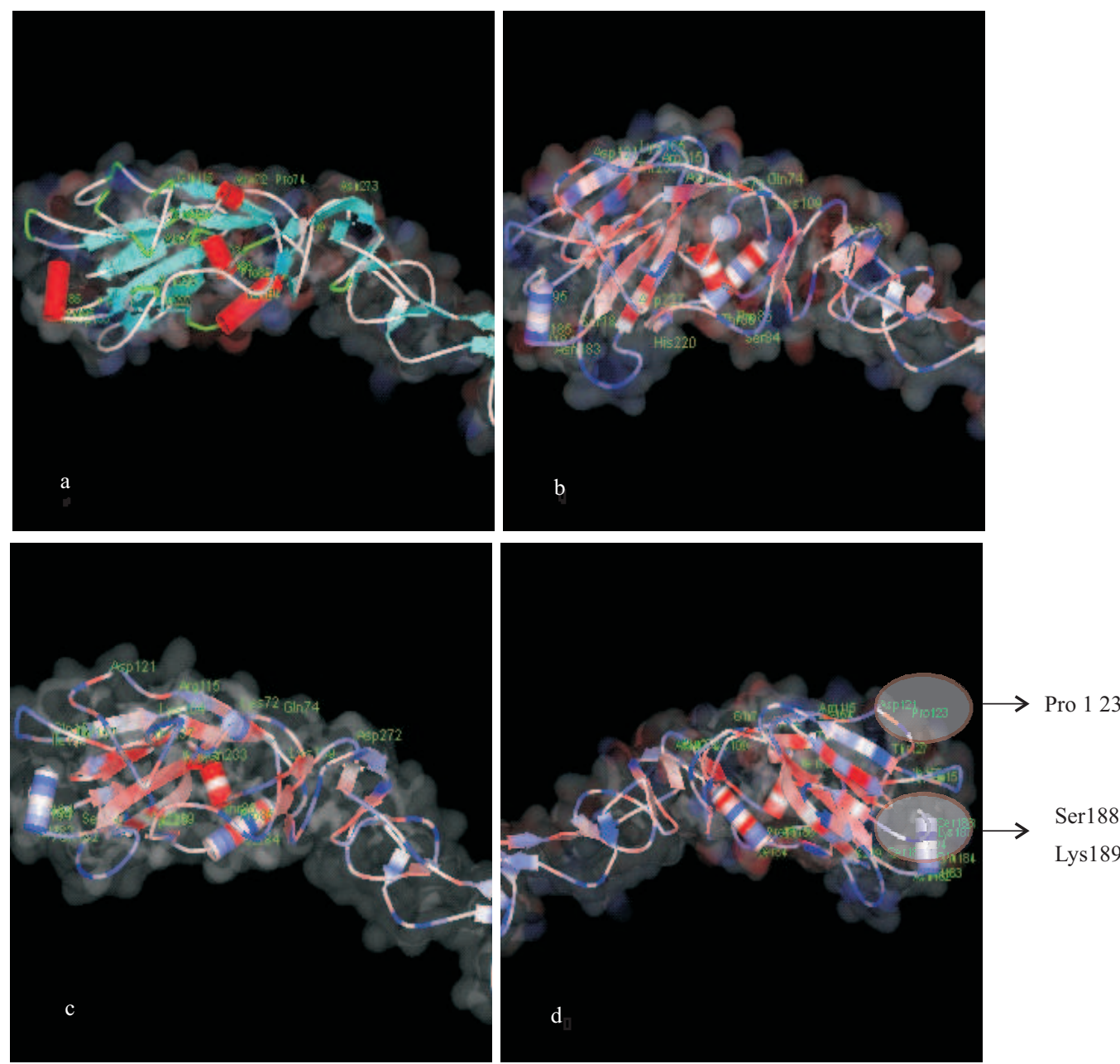

Fig 5 Locations of amino acid substitutions in the HA1 monomer. a, Prediction of A/Ck/East Java/BL-IPA/03 as representative virus from initial 2003 outbreaks; b, Group 1 virus (A/Ck/West Java/Pwt-Wij/06); c, Group 2 virus (A/Ck/West Java/Smi-Sud1/07); and d, Group 3 virus (A/Ck/West Java/Smi-M6/08). The visualization was displayed using Accelrys DS Visualizer 2.1.

diversity of the H5N1 sub-lineage in Indonesia. Also, as acknowledged globally, there needs to be routine monitoring, with adequate virus characterization, to observe the AI virus dynamism in the field and its compatibility to vaccine seed viruses (Chen et al. 2006). This recommendation is important in the larger scope of the Indonesian AI disease control program, where the cooperation of farmers in vaccination will be optimized if the vaccine provided is efficacious and effective.

\section{ACKNOWLEDGEMENT}

We thanks to the Livestock Services in Blitar, Jakarta, Pandeglang, Serang, Bekasi, and Sukabumi districts for the assistance provided during the field work and to Nana Suryana for his technical assistance. This study was funded by State Budget Project in 2008 Agricultural Research and Development of the Indonesian Department of Agriculture. Gina Samaan is funded by the Australian Prime Minister's AustraliaAsia Endeavour Awards.

\section{REFERENCES}

Both GW, Sleigh MJ, Cox NJ, Kendal AP. 1983. Antigenic drift in influenza virus H3 hemagglutinin from 1968 to 1980: multiple evolutionary pathways and sequential amino acid changes at key antigenic sites. J Virol. 48(1):52-60.

Chen H, Smith GJ, Li KS, Wang J, Fan XH, Rayner JM, Vijaykrishna D, Zhang JX, Zhang LJ, Guo CT, Cheung CL, Xu KM, Duan L, Huang K, Qin K, Leung YH, Wu WL, Lu HR, Chen Y, Xia NS, Naipospos TS, Yuen KY, Hassan SS, Bahri S, Nguyen TD, Webster RG, Peiris JS, Guan Y. 2006. Establishment of multiple sublineages of H5N1 influenza virus in Asia: implications for pandemic control. Proc Natl Acad Sci USA. 103(8):2845-2850. doi_10.1073_pnas.0511120103.

Damayanti R, Dharmayanti NLPI, Indriani R, Wiyono A, Darminto. 2004. Deteksi virus avian influenza subtype H5N1 pada organ ayam yang terserang flu burung sangat patogenik di Jawa Timur dan Jawa Barat. JITV. 9(3):197-303.

Dharmayanti NLPI. 2009. Perubahan genom dan karakter virus avian influenza subtipe $\mathrm{H} 5 \mathrm{~N} 1$ dada unggas di Indonesia. [dissertation]. Jakarta (ID): Universitas Indonesia.

Dharmayanti NLPI, Damayanti R, Wiyono A, Indriani R, Darminto. 2004 Identifikasi virus avian influenza virus isolat Indonesia dengan metode reverse transcripatese polymerase chain reaction RT-PCR. JITV. 9(2):136-143.

Dharmayanti NLP I, Ibrahim F, Soebandrio A. 2010. Amantadine resistant of Indonesian H5N1 subtype influenza viruses during 2003-2008. Microbiol Indones. 4(1):11-16. 
Fouchier RAM, Munster V, Wallensten A, Bestebroer TM, Herfst S, Smith D, Rimmelzwaan GF, Olsen B, Osterhaus ADME. 2005. Characterization of novel influenza A virus hemaglutinin subtype (H16) obtained from black-headed gulls. J Virol. 79 (5):2814-2822. doi:10.1128/JVI.79.5.2814-2822.2005.

Guan Y, Poon LLM, Cheung CY, Ellis TM, Lim W, Lipatov AS, Chan KH, Strum-Ramirez KM, Cheung CL, Leung YHC, Yuen KY, Webster RG, Peiris JSM. 2004. H5N1 influenza : a protean pandemic threat. Proc Natl Acad Sci USA. 102 (21):8156-8161. doi: 10.1073/pnas.0402443101.

Hoffmann E, Stech J, Guan Y, Webster RG, Perez D. 2001. Universal primer set for the full-length amplification of all influenza A viruses. Arch Virol. 146 (12):2275-2289. doi: 10.1007/s007050170002.

Koelle K, Cobey S, Grenfell B, Pascual M. 2006. Epochal evolution shapes the phylodynamics of interpandemic influenza A (H3N2) in humans. Science. 314(5807):1898-1903. doi: 10.1126/science.1132745.

Lee MS, Chang PC, Shien JH. Cheng MC, Shieh HP. 2001. Identification and subtyping of avian influenza viruses by reverse transcription-PCR. J Virol Meth. 97(1-2):13-22. 2 doi:10.1016/S0166-0934(01)00301-9.

Li KS, Guan Y, Wang J, Smith GDJ, Xu KM, Duan L, Ronohardjo AP, Puthavathana P, Buranathai C, Nguyen TD, Estoepangestie AT, Chaisingh A, Auewarakul P, Long HT, Hanh NT, Webby RJ, Poon LLM, Chen H, Shortridge KF, Yuen KY, Webster RG, Peiris JSM. 2004. Genesis of highly pathogenic and potentially pandemic H5N1 influnza virus in eastern Asia. Nature. 340(6996):209-213. doi:10.1038/nature02746.

Plotkin JB, Dushoff JB, Levin SA. 2002. Hemagglutinin sequene clusters and the antigenic evolution of influenza A virus. Proc Natl Acad Sci USA. 99(9):6263-6268. doi: 10.1073/pnas.082110799.

Puthavathana P, Auewarakul P, Charoenying PC, Sangsiriwut K, Pooruk P, Boonnak K, Khanyok R, Thawachsupa P, Kijphati R,.Sawanpanyalert P. 2005. Molecular characterization of the complete genome of human influenza H5N1 virus isolates from Thailand. J Gen Virol. 86(Pt 2):423-433. doi: 10.1099/vir.0.80368-0.

Rohm C, Suss JC, Pohle V, Webster RG. 1996. Different hemagglutinin cleavage site variants of H7N7 in an influenza outbreak in chicken in Leipzig, Germany Virol 218(1):253-257. doi:10.1006/viro. 1996.0187.

Schulze IT. 1997. Effect of glycosilation on the properties and functions of influenza virus hemagglutinin. J Infect Dis. 176(Supp11):S24-S28. doi: $10.1086 / 514170$

Senne DA, Panigrahy B, Kawaoka, Y, Pearson JE, Suss, J, Lipkind, M, Kida H, Webster RG. 1996. Survey of the hemagglutinin (HA) cleavage site sequence of $\mathrm{H} 5$ and $\mathrm{H} 7$ avian influenza viruses : amino acid sequence at the HA cleavage site as a marker of pathogenicity potential. Avian Dis. 40(2):425-437.

Shih ACC, Hsiao TC, Ho MS, Li WH. 2007. Simultaneous amino acid substitutions at antigenic sites drive influenza a hemagglutinin evolution. Proc Natl Acad Sci USA. 104.(15):6283-6288. doi: 10.1073/pnas.0701396104.

Smith DJ, Lapedes AS, de Jong JC, Bestebroer TM, Rimmelzwaan GF, Osterhaus AD 2004. Mapping the antigenic and genetic evolution of influenza virus. Science. 305(5682):371-376. doi: 10.1126/science. 1097211.

Swayne,DE, Beck JR, Garcia M, Stone HD. 1999. Influence of virus strain and antigen mass on efficacy of H5 avian influenza inactivated vaccines. Avian Path. 28(3):245255. doi:10.1080/ 03079459994731.

Swayne DE, Kapczynski D. 2008. Strategies and challenges for eliciting immunity against avian influenza virus in birds. Immunol Rev. 225:314331. doi: 10.1111/j.1600-065X.2008.00668.x.

Takano R, Nidom, CA, Kiso M, Muramoto Y, Yamada S, SakaiTagawa Y, Macken C, Kawaoka Y. 2009. Phylogenetic characterization of $\mathrm{H} 5 \mathrm{~N} 1$ avian influenza viruses isolated in Indonesia from 2003-2007. J Virol. 390(1):13-21. doi:10.1016/j.virol.2009.04.024.

Wiyono A, Indriani R, Dharmayanti NLPI, Damayanti R, Darminto. 2004. Isolasi dan Karakterisasi Virus Highly Pathogenic Avian Influenza subtipe H5 dari ayam asal Wabah di Indonesia. JITV. 9(1):61-71

[WHO] World Health Organization. 2005. Global influenza program surveillance network. Evolution of $\mathrm{H} 5 \mathrm{~N} 1$ avian influenza viruses in Asia. Emerging Infect Dis. 11(10): 1515-1521. 